\title{
UPAYA MERAIH JABATAN PEMIMPIN PERSPEKTIF HADIS AHKAM
}

\author{
Toha Andiko \\ Fakultas Syariah IAIN Bengkulu \\ Jl. Raden Fatah Pagar Dewa Bengkulu \\ Email: toha.andiko@gmail.com
}

\begin{abstract}
In public leadership, Islamic history records that succession occurred after the death of the Holy Prophet was carried out with various variants. The traditions of the Prophet who spoke about leadership, the majority discussed the ethical principles of the position of leader. Only a few hadiths discuss the law of trying to reach a leadership position, and that is generally understood as a prohibition. In fact, in the Indonesian context, for example, there is no public leadership that can be achieved without effort. This paper explains that the effort to reach a leadership position is basically not prohibited. The prohibition on asking for office in the traditions of the Prophet was actually addressed to people who were greedy and incompetent. As for someone who has more ability than most of his community, whether intellectual, managerial or other strengths that can support his leadership in the future, then the law is permissible.
\end{abstract}

Keywords: Leadership Position; Legal Hadith; Permissible

\begin{abstract}
Abstrak: Dalam kepemimpinan publik, sejarah Islam mencatat bahwa suksesi yang terjadi setelah wafatnya Nabi saw dilaksanakan dengan berbagai varian. Hadis-hadis Nabi saw yang berbicara tentang kepemimpinan, mayoritasnya membahas tentang prinsip-prinsip etika terhadap jabatan pemimpin. Hanya sedikit hadis yang membahas tentang hukum upaya meraih jabatan pemimpin, dan itupun umumnya dipahami sebagai larangan. Padahal, dalam konteks Indonesia misalnya, tidak ada kepemimpinan publik yang dapat diraih tanpa usaha. Tulisan ini menjelaskan bahwa upaya meraih jabatan pemimpin pada dasarnya tidak dilarang. Larangan meminta jabatan dalam hadis-hadis Nabi saw sebenarnya ditujukan kepada orang yang tamak dan tidak kompeten. Adapun bagi seseorang yang memiliki kemampuan lebih dibanding kebanyakan masyarakatnya, baik kemampuan intelektual, manajerial atau kelebihan lain yang dapat mendukung kepemimpinannya kelak, maka hukumnya mubah.
\end{abstract}

Kata kunci: jabatan pemimpin, hadis ahkam, mubah

\section{Pendahuluan}

Dalam ajaran Islam, pembahasan tentang kepemimpinan memperoleh perhatian yang sangat besar. Dalam Alquran, banyak terdapat istilahistilah yang bermakna kepemimpinan. Misalnya kata Imam (QS.Al-Baqarah: 124), Khalifah (AlBaqarah: 30), Malik (Al-A`raf: 3), Ulil Amri (AlNisa': 59), dan Sulthan (Al-Nisa': 144). Begitu juga dalam hadis, Nabi saw misalnya pernah bersabda: "Apabila 3 orang keluar dalam suatu perjalanan (safar), maka hendaklah mereka mengangkat salah seorang di antara mereka sebagai pemimpin" (HR. Abu Daud). Dan dalam hadis lainnya Nabi saw menjelaskan "Ingatlah, setiap kamu adalah pemimpin, dan setiap pemimpin akan dimintai pertanggungjawabannya”. (HR. Bukhari Muslim). Bahkan untuk menguatkan urgensi kepemimpinan yang memiliki kekuasaan dalam suatu komunitas, sampai-sampai Ibnu Taimiyah mengatakan "agama Islam tidak akan bisa tegak dan abadi tanpa kekuasaaan, dan kekuasaan tidak bisa langgeng tanpa ditunjang dengan agama”. Ini menunjukkan bahwa agama tidak bisa dilepaskan dari politik, termasuk kekuasaan yang diperoleh melaui jabatan pemimpin.

Dalam kepemimpinan publik, suksesi yang terjadi dalam sejarah Islam terjadi dengan berbagai varian. Setelah Nabi Muhammad saw wafat, Abu Bakar Siddiq terpilih sebagai pemimpin melalui pemilihan sistem perwakilan 
terbatas. Umar bin Khattab terpilih sebagai pemimpin melalui penunjukan langsung oleh Abu Bakar berdasarkan wasiatnya. Usman bin Affan terpilih sebagai pemimpin melalui sistem formatur yang terdiri dari 5 orang yang ditunjuk oleh Umar bin Khattab, dan Ali bin Abi Thalib terpilih sebagai pemimpin dalam suasana chaos yang diangkat oleh para pemberontak yang mendukungnya, lalu kemudian masyarakat ikut membaiatnya. Oleh sebab itu, pada dasarnya ajaran Islam tidak mengatur teknis khusus tentang cara meraih jabatan. Hadis-hadis Nabi saw yang berbicara tentang kepemimpinan, mayoritasnya membahas tentang prinsip-prinsip etika terhadap jabatan pemimpin.

Dalam konteks Indonesia, kepemimpinan publik (Bupati, Walikota, Gubernur, Presiden) ditentukan melalui pemilihan umum yang berlangsung 5 tahun sekali. Di satu sisi, mayoritas umat Islam di Indonesia menginginkan pemimpin yang baik dengan 4 sifat Nabi (shiddiq, amanah, tabligh, fathanah) yang melekat padanya. Tapi di sisi lain, tidak sedikit orang Islam yang telah memenuhi atau mendekati 4 sifat Nabi tersebut, enggan untuk mengajukan diri menjadi pemimpin karena khawatir termasuk ambisi terhadap jabatan sebagaimana larangan Nabi kepada Abdurrahman bin Samrah. Karena proses untuk menjadi pemimpin di Indonesia, mengharuskan yang bersangkutan aktif, mulai dari pendaftaran, melengkapi persyaratan yang ditetapkan oleh KPU, hingga kampanye. Oleh sebab itu, pada tulisan ini akan dibahas hadishadis yang dianggap sebagai hadis ahkam (mengandung hukum) tentang upaya meraih jabatan pemimpin.

\section{Mekanisme Suksesi Kepemimpinan}

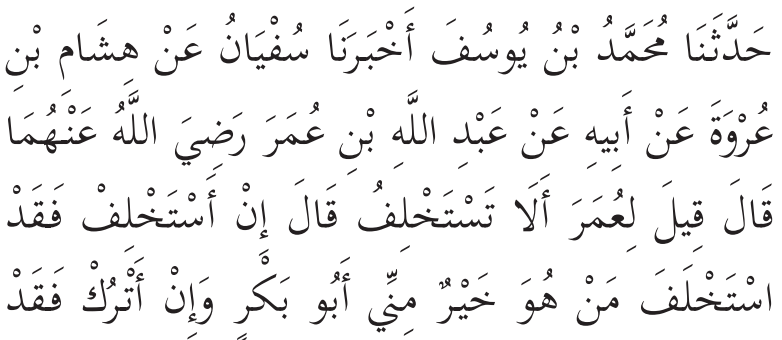

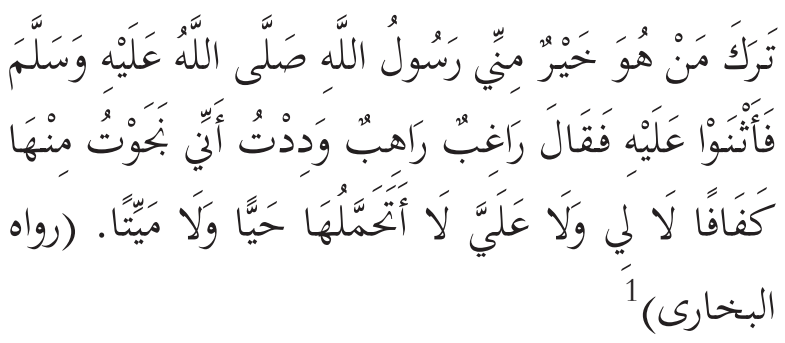

"Diceritakan kepada kami oleh Muhammad ibn Yusuf, dikhabarkan Sofyan kepada kami dari Hisyam ibn 'Urwah dari Ayahnya diriwayatkan dari Umar, dari Abdullah bin Umar r.a. katanya, "Umar telah ditanya, "Mengapa engkau tidak mencari orang yang akan menjabat sebagai khalifah (penggantimu)? Ayahku menjawab "Sekiranya aku mencari orang yang akan menjabat sebagai khalifah (penggantiku), orang yang lebih baik daripada aku, yaitu Abu Bakar, telah melakukannya. Akan tetapi, apabila aku menyerahkan masalah (suksesi) kepemimpinan ini kepada masyarakat banyak, orang yang lebih baik daripada saya yaitu Rasulullah saw. telah menyerabkan suksesi kepemimpinan (kepada mereka). Maka mereka pun memuji sikap Umar tersebut. Kemudian Umar berkata, "Sebenarnya aku ingin sekali (menentukan suksesi kepemipinan ini), tetapi aku juga takut untuk menentukannya. Aku ingin sekali terbebas (bersikap bijak) dalam masalah suksesi kepemimpinan ini sehingga ia tidak menjadi sebuah kesenangan, tetapi juga tidak menjadi sebuah kemudharatan bagiku dan tidak menjadi beban bagi kehidupan dan kematianku." (HR. Bukhari).

\section{Tinjauan Sanad:}

Muhammad ibn Yusuf nama lengkapnya adalah: Muhammad ibn Yusuf bin 'Aqid bin Usman. Ia termasuk Tabi al-Tabiin pertengahan. Nasabnya adalah al-Dhahiy alFaryabiy, Kuniyahnya adalah Abu Abdillah, Ia bermukim di Syam, wafat tahun 212 H. Ia termasuk perawi yang tsiqah, tetapi pernah tersalah dalam periwayatan hadis Sufyan ${ }^{2}$

\footnotetext{
${ }^{1}$ Muhammad ibn Ismail Abu Abdillah al-Bukhari, Shahih al-Bukhari, (Beirut: Dar Ibnu Katsir, 1907), Cet. III, Juz VI, h. 2638 dalam Kitab al-Ahkam, bab al-Istikhlaf, nomor hadis 6678 .

2 Muhammad ibn Ismail Abu Abdillah al-Bukhari, al-
} 
Sufyan, nama lengkapnya adalah: Sufyan ibn Sa'id ibn Masruq, ia termasuk dalam tabaqah Tabi al-Tabin besar, nasabnya adalah al-Tsaury, Kuniyahnya Abu Abdillah, Ia termasuk orang yang shalih, zahid, 'abid, dan faqih, bermukim di Kufah dan meninggal di Bashrah pada tahun $161 \mathrm{H}$. Ia termasuk perawi yang hafiz, tsiqah dan kadang-kadang mudallas. ${ }^{3}$

Hisyam ibn 'Urwah, nama aslinya adalah: Hisyam ibn 'Urwah ibn Zubair ibn `Awwam, ia termasuk dalam tabaqah Tabi in kecil, Nasabnya al-Asady, kuniyahnya adalah Abu al-Manzar, ia merupakan warga Madinah yang lahir tahun $60 \mathrm{H}$ dan meninggal di Baghdad pada tahun $145 \mathrm{H}$. Ia seorang yang faqih, hafiz dan wara', termasuk perawi yang tsiqah dan kadang-kadang mudallas. ${ }^{4}$

Ayah Hisyam bernama 'Urwah, nama lengkapnya adalah 'Urwah ibn Zubair ibn 'Awwam ibn Khuwailid ibn Asad ibn Abdul Aziz ibn Qushai. Ia tergolong kepada tabaqah Tabi in pertengahan, nasabnya adalah al-Asadiy, kuniyahnya Abu Abdillah, terkenal sebagai seorang faqih penduduk Madinah, lahir di awalawal pemerintahan Usman dan wafat tahun 94 H. Termasuk rawi yang tsiqah, tetapi kadangkadang mudallas. ${ }^{5}$

Tarikh al-Kabir, (Muassasah al-Kutub al-Tsaqafiyah, t. th.), Juz I, h. 264. Syamsuddin Muhammad ibn Ahmad al-Zahabi, al-Muqtani fi Sirad al-Kuniy, (al-Madinah al-Munawarah: Mathabi' al-Jami`ah al-Islamiyah, 1408 H), Juz I, h. 67. Muslim ibn al-Hajjaj, al-Kuniy wa al-Asma', (t.tp.: al-Jami'ah al-Islamiyah, 1984) Juz I, h. 500. Ibnu Abi Hatim, al-Jarh wa al-Ta'dil, (t. tp.: Haidar Abad al-Dakkan, 1952), Juz VIII, h. 119. al-'Ijliy Ma'rifat al-Tsiqat, (Madinah al-Munawwarah: Maktabah al-Dar, 1985), Juz II, h. 257.

${ }^{3}$ al-Bukhari, al-Tarikh al-Kabir, Juz IV, h. 92. Abdurrahman ibn Abi Bakr al-Suyuthi, Thabaqat al-Huffaz, (Beirut: Dar AlKutub al-'Ilmiyyah, 1403H), Juz I, h. 95.Ibnu Abi Hatim, alJarh wa al-Ta'dil, Juz II, h. 222. al-'Ijliy, Ma'rifat al-Tsiqat, Juz I, h. 407.

4 Jamal al-Din al-Mizi, Tahdzib al-Kamal, (Beirut: Mu'assasah al-Risalah, t. th.) Juz XXX, h. 232. al-Bukhari, alTarikh al-Kabir, Juz VIII, h. 193. Ibnu Abi Hatim, al-Jarh wa al-Ta'dil, Juz IX, h. 63. Ibnu Hajar al-'Asqalaniy, Taqrib alTahdzib, (Suriya: Dar al-Rasyid, 1986), Juz I, h. 573. al-Suyuthi, Thabaqat al-Huffazh, Juz I, h. 69. al-'Ijliy, Ma'rifat al-Tsiqat, Juz II, h. 332. Ibnu Hibban, al-Tsiqat, (Haidar Abad al-Dakkan, 1973), Juz V, h. 502. Ahmad ibn Ali ibn Hajar al-'Asqalani, Thabaqat al-Mudallisin, ('Amman: Maktabah al-Manar, 1983), Cet I, Juz I, h. 26.

${ }^{5}$ al-Zahabi, al-Muqtani fi Sirad al-Kuniy, Juz I, h. 349. al-
Abdullah ibn Umar ini nama lengkapnya adalah Abdullah ibn Umar al-Khatthab al-Adawi Abu Abd al-Rahman al-Makki telah masuk Islam sejak kecil di Mekah dan ikut hijrah bersama ayahnya. Ia menyaksikan perang Khandaq dan Bai at al-Ridwan. Ia meriwayatkan 1.630 hadis. Di antara orangorang yang meriwayatkan hadis darinya adalah Salim, Hamzah, Ubaidillah, dan lainnya. Ia termasuk sahabat yang zahid dan wara', seorang imam yang luas ilmu pengetahuan dan banyak pengikutnya. Ia meninggal dunia pada usia 87, tahun $94 \mathrm{H}$ di Mekah dan dimakamkan di sana. Tidak diragukan ketsiqatannya karena ia tergolong kepada golongan Sahabat. ${ }^{6}$

\section{Tinjauan Matan:}

Hadis ini berkualitas shahih, mauquf muttashil. Hadis ini juga diriwayatkan oleh Muslim dalam kitab al-Imarah nomor hadis 3400, Tirmidzi dalam kitab al-Fitan 'an Rasulillah nomor hadis 2151, Abu Dawud dalam kitab al-Kharaj wa alImarah wa al-Fai, dan Ahmad dalam kitab Sanad al-Asyrah al-Mubasysyirin bi al-Jannah nomor hadis 282 dan 314.

Berkenaan dengan suksesi kepemimpinan ini, Amir al-Mukmin, Umar ibn Khattathab telah menyikapinya secara bijak. Ia mengatakan, "sebenarnya aku ingin sekali (menentukan suksesi kepemimpinan ini), tetapi aku juga takut untuk menentukannya. Aku ingin sekali terbebas (bersikap bijak) dalam masalah suksesi kepemimpinan ini sehingga ia tidak menjadi sebuah kesenangan, tetapi juga tidak menjadi sebuah kemudharatan bagiku, dan tidak menjadi beban bagi kehidupan dan kematianku."

Mizi, Tahdzib al-Kamal,, Juz XX, h. 11. Ahmad ibn Ali ibn Hajar al'Asqalani, Taqrib al-Tahdzib, (Suriya: Dar al-Rasyid, 1986), Cet. I, Juz I, h. 389 Muhammad ibn Ismail Abu Abdillah al-Bukhari, al-Tarikh al-Kabir, Juz I, h. 201. Ibnu Hibban, Masyahir Ulama' al-Amshar, (Beirut: Dar al-Kutub al-'Ilmiyyah, t. th.), Juz I, h.64. Muslim ibn al-Hajjaj, al-Kuniy wa al-Asma', Juz I, h. 474. al-Suyuthi, Thabaqat al-Huffazh, Juz I, h. 29. Ibnu Abi Hatim, al-Jarh wa al-Ta'dil, (Haidar Abad al-Dakkan, 1952), Juz 6, h. 395. al-'Ijliy, Márifat al-Tsiqat, Juz II, h. 133

${ }^{6}$ Al-Zahabi, al-Muqtani fi Sirad al-Kuniy, Juz II, h. 55. alBukhari, al-Tarikh al-Kabir, Juz V, h. 2. Ibnu Hibban, al-Tsiqat, Juz VIII, h. 356. 
Sikap ini menunjukkan kehati-hatian Umar dalam menyikapi suksesi yang merupakan masalah besar yang tidak boleh disikapi secara sembarangan. Hal ini karena masalah suksesi kepemimpinan akan menentukan masa depan umat karena baik atau buruk, dan maju mundurnya umat berada di tangan pemimpinnya. Hal ini berarti bahwa seseorang yang akan diserahi jabatan kepemimpinan harus memiliki keunggulan atau karakteristik tertentu seperti pengenalan tehadap dirinya sendiri, yaitu sejauh mana dia telah siap untuk menjadi seorang pemimpin, serta keagamaan dan ketakwaannya, keadilan dan kejujurannya, keterpercayaan dan penetapannya terhadap sebuah janji yang telah diungkapkan, keilmuan dan keberaniannya dalam menangani masalah kepemimpinan, kedermawanan dan kasih sayangnya, kesabaran dan pengendalian dirinya, kekuatan dan kemampuan managerialnya, dan lain-lain.

Dari penjelasan hadis di atas, dapatlah kiranya diambil beberapa pemahaman bahwa suksesi kepemimpinan adalah suatu keharusan dalam sebuah komunitas yang akan mengurusi berbagai permasalahan umat, baik dalam masalah perekayasaan kehidupan duniawi dengan berbagai aspeknya maupun penegakan agama. Selain itu, sunnatullah menyatakan bahwa di antara manusia terdapat orang-orang yang memiliki keunggulan tertentu yang dapat mendominasi sesamanya.

Dalam menentukan suksesi kepemimpinan, setiap orang harus bersikap bijak sehingga tidak ada pihak-pihak yang merasa dirugikan. Penentuan siapa yang akan menjabat sebagai pemimpin harus selektif sehingga tidak memberikan suatu hak kepada orang yang bukan pemiliknya yang selanjutnya akan menimbulkan kehancuran umat itu sendiri.

Suksesi kepemimpinan dapat dilakukan berdasarkan penunjukan pemimpin sebelumnya atau diserahkan kepada komunitas untuk memilih dan menunjuknya. Dan seseorang yang akan menjabat pimpinan tersebut haruslah orang yang memiliki karakteristik tertentu dan memenuhi syarat-syarat pemimpin yang dapat menunjang kelancaran kepemimpinannya.

\section{Ambisi Jabatan Pemimpin}

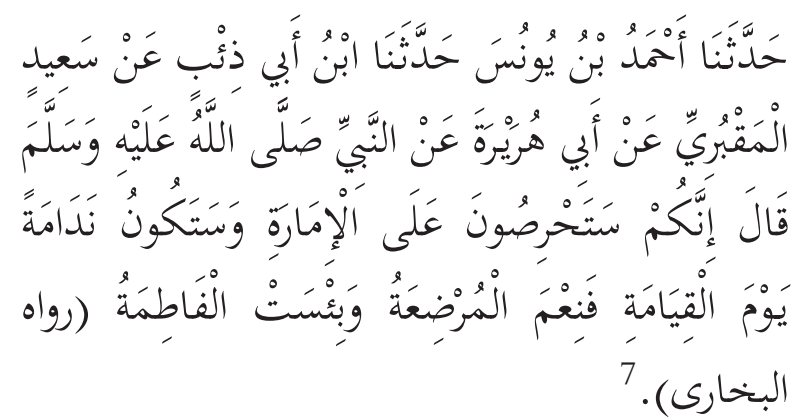

"Diceritakan kepada kami oleh Ahmad ibn Yunus, diceritakan kepada kami oleh Ibnu Abi Dzib dari Said al-Maqburiy, diriwayatkan dari Abu Hurairah r.a. dia berkata: "Rasulullah saw. Bersabda: "Sesungguhnya kamu sekalian sangat menginginkan kepemimpian dan akan menjadi penyesalan di hari kiamat. Sesungguhnya kepemimpinan adalah kehidupan yang paling menyenangkan, tetapi membawa akibat yang paling jelek dalam kematian". (H.R. Bukhari).

\section{Tinjauan Sanad:}

Ahmad ibn Yunus nama lengkapnya adalah Ahmad ibn Abdullah ibn Yunus ibn Abdullah ibn Qais al-Tamimiy al-Yarbu'iy, kuniyahnya Abu Abdillah. Ia termasuk tingkatan Tabi al-Tabiin besar, bermukim di Kufah dan wafat di sana tahun $227 \mathrm{H}$. Ia adalah orang yang hafiz dan $t_{\text {siqa }}{ }^{8}$

Ibnu Abi Zi'b nama lengkapnya Muhammad ibn Abdurrahman ibn Mughirah ibn Harits ibn Abi Zi'b, kuniyahnya Abu al-Harits. Ia termasuk tingkatan Tabi in besar, bermukim di Madinah dan wafat di Kufah tahun $158 \mathrm{H}$. Ia adalah orang yang tsiqah dan adil. ${ }^{?}$

${ }^{7}$ Al-Bukhari, Shahih al-Bukhari, h. 2613, Kitab Al-Ahkam, Bab Ma Yakrahu Minal Harshi ala al-Imarah, No. Hadits 6615. Hadits ini juga diriwayatkan oleh Nasa'i dengan sanad yang berbeda lewat jalur Muhammad ibn Adam ibn Sulaiman, dari Mubarak dari Abi Dzi'b dari Said al-Maqburiy dari Abu Hurairah.

${ }^{8}$ Muslim ibn al-Hajjaj, al-Kuniy wa al-Asma', Juz I, h.504. al-Bukhari, al-Tarikh al-Kabir, Juz II, h. 5. al-Suyuthi, Thabaqat al-Huffaz, Juz I, h. 177. Ibnu Abi Hatim, al-Jarh wa al-Ta'dil, Juz II, h. 57.

${ }^{9}$ Abi al-Hasan ibn Ali ibn Umar ibn Ahmad al-Daruqutniy, 
Said al-Maqburiy nama lengkapnya adalah Said ibn Abi Said Kisan al-Maqburiy, kuniyahnya Abu Sa'ad. Ia termasuk tingkatan Tabi in pertengahan, bermukim di Madinah dan wafat di sana tahun $123 \mathrm{H}$. Ia adalah orang yang tsiqah dan adil. ${ }^{10}$

Abu Hurairah adalah Abdurrahman ibn Shakhar al-Yamani al-Dausi. Kuniyahnya sekaligus namanya. Ia masuk Islam pada masa Khaibar tahun ke-7 H. Dia seorang yang faqih mujtahid sekaligus hafizh meriwayatkan hadis sebanyak 5.374 hadis. Oleh sebab itu, ia termasuk sahabat yang paling banyak meriwayatkan hadis. Ia lahir di Madinah, masuk Islam pada tahun ke-7 $\mathrm{H}$, dan meninggal pada tahun $57 \mathrm{H}$ dalam usia 78 tahun dan dimakamkan di Madinah. Ia termasuk tingkatan sahabat dan dikenal sebagai orang yang adil dan tsiqah. ${ }^{11}$

\section{Tinjauan Matan:}

Kualitas hadis di atas shahih dan marfu' muttashil. Hadis tersebut dalam Shahih Bukhari tercantum dalam kitab al-Ahkam nomor hadis 6615, dan yang semakna dengannya juga diriwayatkan oleh Nasai pada Sunan al-Nasai dalam kitab al-Baiah nomor hadis 4140 dan kitab Adab al-Qudhat nomor hadis 5290, begitu juga pada Musnad Ahmad dalam kitab Baqiy Musnad al-Mukatssirin nomor hadis 9415 dan 9774.

Zikru Asma' al-Tabi in wa Man Ba'dahum, (Beirut: Mu'assasah al-Kutub al-Tsaqafiyah, 1985), Cet. I, Juz I, h. 319. al-Zahabiy, Siyar A 'lam al-Nubala’, (Makkah: Mu’assasah ar-Risalah, 1981) Juz VII, h. 139. al-Zahabiy, Mizan al-I'tidal fi Naqd al-Rijal, (Beirut: Dar al-Márifah, t.th.), Juz VI, h. 229

${ }^{10}$ Muslim ibn al-Hajjaj, al-Kuniy wa al-Asma', Juz I, h. 392. al-Zahabi, Al-Muqtani fi Sirad al-Kuniy, Juz I, h. 341. alDaruqutniy, Zikru Asma' al-Tabi in wa Man Ba'dahum, Juz I, h. 147. al-'Ijliy, Ma'rifat al-Tsiqat, Juz I, h. 399. al-Zahabiy, Mizan al-I'tidal fi Naqd ar-Rijal, Juz III, h. 204. Ibnu al-Jauzi, AlDhu 'afa' wa al-Matrukin, (Beirut: Dar al-Kutub al-'Ilmiyyah, 1986), Juz I, h. 311

${ }^{11}$ al-Zahabi, al-Muqtani fi Sirad al-Kuniy, Juz II, h. 125. al-Zahabiy, Siyar A 'lam al-Nubala', Juz II, h. 578. Ibnu Hibban, al-Tsiqat, Juz III, h. 284. al-'Ijliy, Márifat al-Tsiqat, Juz II, h. 433. Ibnu Hibban, Masyahir 'Ulama al-Amshar, Juz I, h. 15. al-Suyuthi, Thabaqat al-Huffaz, Juz I, h. 17. Ahmad ibn Ali ibn Hajar al-'Asqalani, al-Ishabah, (Beirut: Dar al-Jalil, 1992), Cet. I, Juz IV, h. 316. Abu al-Walid al-Bajiy, al-Tajrih wa al-Ta'dil, (Riyadh, Dar al-Liwa', 1986), Juz III, h. 1276
Kata "satahrishuna 'ala" adalah istilah yang digunakan untuk menunjukkan kecintaan jiwa manusia. Bila digandengkan dengan kata "al-imarah", maka kata ini menunjukkan kecenderungan manusia untuk mencintai dan mendapatkan kekuasaan, yang di dalamnya terdapat kemegahan kehidupan dunia, kenikmatan, dan status sosial yang tinggi. ${ }^{12}$

Kata "nimat al-murdhiah" menunjukkan berbagai manfaat dan kesenangan-kesenangan duniawi seperti kondisi kemuliaan, harta kekayaan, dan status sosial seseorang yang sangat dijunjung tinggi, sedang kata "bi'sat al-fathimah" menunjukkan terputusnya kesenangan dan mannfaat-manfaat duniawi lainnya sehingga menjadi orang yang merugi karena kondisinya tanpa kemuliaan, tanpa harta kekayaan, dan tanpa kemegahan status sosial, yaitu kondisi yang menimpa orang-orang yang kehilangan jabatannya atau meninggal dunia. ${ }^{13}$ Bisa juga berarti kesempitan dalam hidup dan penderitaan yang melebihi dari nikmat yang pernah diperoleh. ${ }^{14}$

Dari hadis ini dipahami bahwa orang yang sangat berambisi dan tamak terhadap jabatan kepemimpinan dan menjadikan jabatannya tersebut sebagai alat untuk mencapai kemegahan duniawi dan bersenang-senang dengannya niscaya akan mengalami kesulitan dan berbagai hambatan dalam menjalankan tugas-tugasnya sebagai pemimpin, sehingga iapun akan menyesal di akhir hayatnya karena pasti selalu mengalami hal-hal buruk yang dapat menyengsarakannya.

\section{Makna Larangan Meminta Jabatan Pemimpin}

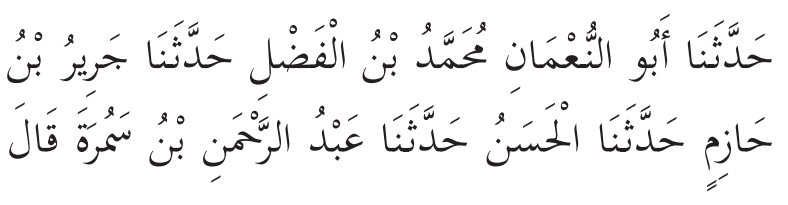

12 Ibrahim ibn Muhammad al-Husaini, ditahqiq oleh Saifuddin al-Katib, al-Bayan wa al-Tárif, (Beirut: Dar al-Kitab al-Arabiy, 1401H), Juz I, h. 254.

${ }^{13}$ Al-Husaini, al-Bayan wa al-Tárif, h. 255.

${ }_{14}$ Muhammad ib Ismail al-Shan'ani, Subul al-Salam Syarh Bulugh al-Maram Min Adillat al-Ahkam, (Beirut: Dar Ihya alTuras al-Arabiy, 1379H), Juz II, h. 555. 


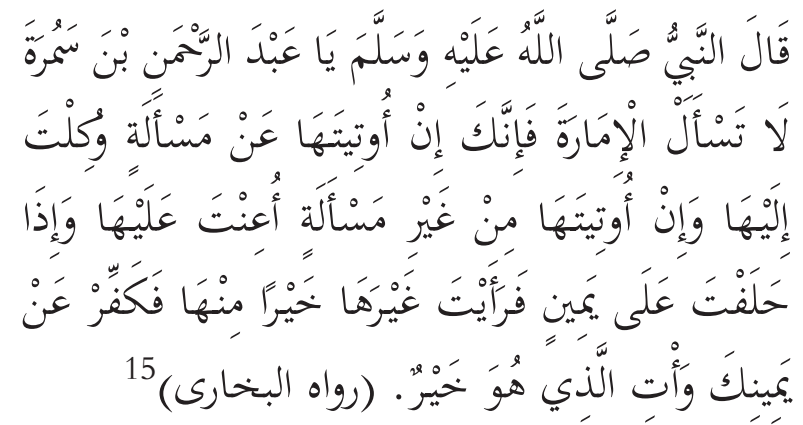

"Diceritakan kepada kami oleh Abu al-Numan Muhammad ibn al-Fadhl, diceritakan kepada kami oleh Jarir ibn Hazim, diceritakan kepada kami oleh al-Hasan, diriwayatkan dari Abdul Rahman ibn Samurah r.a. katanya, Rasulullah Saw. bersabda, "Wahai Abdul Rahman bin Samurah, janganlah kamu memohon untuk menjadi pemimpin. Sesungguhnya jika kepemimpinan diberikan kepada kamu melalui permohonan, maka kamu akan dibebani tanggung jawab sebagai seorang pemimpin. Dan jika jabatan pimpinan diberikan kepada kamu tanpa melalui permohonan, maka kamu akan mendapatkan pertolongan (dukungan dalam kepemimpinan). Dan jika kamu telah melaksanakan sumpah jabatan, lalu kamu lihat ada orang lain yang lebih baik untuk jabatan itu, maka batalkanlah sumpahmu dan berikanlah (jabatan itu) kepada orang yang lebih baik itu." (HR. al-Bukhari).

\section{Tinjauan Sanad:}

Abu Nu'man nama lengkapnya adalah Muhammad ibn al-Fadhl al-Sadusiy. Kuniyahnya Abu al-Nu'man, laqabnya 'Arim. Ia termasuk tingkatan Tabi' in kecil, salah satu guru Imam al-Bukhari, bermukim di Bashrah dan wafat tahun $224 \mathrm{H}$ di Bashrah. Ia seorang yang hafiz, shaduq, dan dikenal sebagai orang yang tsiqah tsiqah. ${ }^{16}$

${ }^{15}$ Muhammad ibn Ismail Abu Abdillah al-Bukhari, Shahih al-Bukhari, kitab al-Iman wa al-Nuzur, bab Qaulubu Táala La Yu'akhizukumullah Billaghwi fi Imanikum, nomor hadis 6132.

${ }^{16}$ Muslim ibn al-Hajjaj, al-Kuniy wa al-Asma', Juz I, h. 845. Ad-Daruqutniy, Zikru Asma' al-Tabi in wa Man Ba'dahum, Juz I, h. 330. al-Bukhari, al-Tarikh al-Kabir, Juz I, h, 208. Ibnu Abi Hatim, al-Jarh wa al-Ta dil, Juz VIII, h. 58. Al-Zahabiy, Mizan al-I'tidal fi Naqd al-Rijal, Juz VI, h. 298. Ahmad ibn Ali ibn Hajar al- 'Asqalani, Lisan al-Mizan, (Beirut: Mu'assasah alA'lami al-Mathbu’at, 1986), Cet. III, Juz VII, h. 37. Abu Nashr
Jarir ibn Hazim nama lengkapnya adalah Jarir ibn Hazim ibn Zaid al-Azdiy al-Atkiy, kuniyahnya Abu Nadhr. Ia lahir tahun $88 \mathrm{H}$, termasuk Tabi'in kecil (shighar at-tabi in) yang tidak sempat berjumpa sahabat, bermukim di Bashrah, terkenal sebagai hafiz, dan wafat tahun $170 \mathrm{H}$. Ia adalah orang yang shaduq, shalih, tsiqah dan adil. ${ }^{17}$

Al-Hasan nama lengkapnya al-Hasan ibn Abi al-Hasan Yasar al-Bashry, kuniyahnya Abu Sa id. Ia lahir setelah 2 tahun pemerintahan Umar, termasuk tingkatan Tabi in pertengahan. Iapun masih sempat melihat Usman dan mendengar khutbahnya, bermukim di Bashrah dan wafat pada bulan Rajab tahun $110 \mathrm{H}$ dalam usia mendekati 90 tahun. Ia adalah orang yang shalih, termasuk salah seorang fuqaha al-amshar, pemuka Tabi in, dikenal sebagai orang yang tsiqah dan adil. ${ }^{18}$

Abdurrahman ibn Samurah nama lengkapnya adalah Abdurrahman ibn Samurah ibn Habib ibn Abd Syams al-Absyami, kuniyahnya Abu Said. Ia termasuk tingkatan sahabat yang masuk Islam pada hari penaklukan kota mekah. Menurut satu pendapat, namanya adalah Abd al-Kalam, namun pendapat lain menyangkalnya. Nabi saw menyebutnya Abd al-Rahman. Ia masuk Islam pada waktu fathu Makkah, tinggal di Bashrah dan dialah yang membuka atau menaklukkan Sijistan, Kabil, dan lainnya. Ia juga termasuk sahabat yang ikut menyaksikan atau mengikuti perang Mu'tah. Ia meninggal dunia pada tahun $50 \mathrm{H}$ di Bashrah.

al-Kalabadzi, Rijal Shahih al-Bukhari, (Beirut: Dar al-Ma'rifah, 1987), Juz II, h. 674. Abu al-Walid al-Bajiy, al-Tajrih wa alTa'dil, Juz II, h. 675

${ }^{17}$ al-Zahabiy, Siyar A'lam an-Nubala', Juz VII, h. 98. Muslim ibn al-Hajjaj, al-Kuniy wa al-Asma', Juz I, h. 841, Ibnu Hibban, Masyahir Ulama al-Amshar, Juz I, h. 159. al-Bukhari, al-Tarikh al-Kabir, Juz II, h. 213. al-Kalabadzi, Rijal Shahih al-Bukhari, Juz I, h. 144. Ibnu Abi Hatim, al-Jarh wa al-Ta'dil, Juz II, h. 504, al-Zahabiy, Mizan al-I'tidal fi Naqd al-Rijal, Juz II, h. 117. Umar ibn Ahmad Abu Hafsh al-Wa 'izh, Tarikh Asma’ al-Tsiqat, (Kuwait: al-Dar al-Salafiyah), Cet. I, Juz I, h. 56. Ibnu Hibban, al-Tsiqat, Juz VI, h. 144.

${ }^{18}$ Muslim ibn al-Hajjaj, al-Kuniy wa al-Asma', Juz I, h. 357. al-Bukhari, al-Tarikh al-Kabir, Juz II, h, 289. al-'Asqalaniy, Taqrib al-Tahdzib, Juz I, h. 160. Ibnu Abi Hatim, al-Jarh wa al-Ta'dil, Juz III, h. 40. al-'Ijliy, Ma'rifat al-Tsiqat, Juz I, h. 292.. 
Dia meriwayatkan hadis dari Muadz ibn Jabal dan dari Nabi saw. Iapun dikenal adil dan tsiqah. Adapun orang-orang yang meriwayatkan hadis darinya di antaranya adalah Hibban ibn Umair, Abd al-Rahman ibn Abi Ya'la, Hisban ibn Kahin, al-Hasan Bashri, Abu Lubaid Lumazah, dan lain-lain. ${ }^{19}$

\section{Tinjauan Matan:}

Hadis tersebut di atas kualitasnya juga shahih dan marfu: Hadis ini pada Shahih Bukhari tercantum pada kitab "al-Aiman wa al-Nudzur" dalam bab "Qaul Allahi Tảala La yu'akhidzukum Allahu bi al-laghwi fi Aymanikum" nomor hadis 6132. Sedang hadis yang semakna dengannya juga didapatkan dalam Sahih Muslim pada kitab al-Aiman nomor hadis 3120 dan kitab al-imarah nomor hadis 3401, dalam Sunan Tirmidzi pada kitab al-Nudzuru wa al-Aimanu 'an Rasulillah nomor hadis 1449, dalam Sunan al-Nasa'i pada kitab al-Aimanu wa al-Nudzuru nomor hadis 3722, 3723, 3724, dan kitab Adab al-Qudhat nomor hadis 5289, dalam Sunan Abi Dawud pada kitab al-Kharaj wa al-Imarah wa al-Faiu nomor hadis 2540 dan kitab alAiman wa al-Nudzur nomor hadis 2852, dalam Musnad Ahmad pada kitab Awwal Musnad alBashariyyin nomor hadis 19702, 19704, 19712, dan dalam Sunan Darimi pada kitab al-Nudzur wa al-Aiman nomor hadis 2241.

Kata "al-imarah" berarti al-wilayah atau kekuasaan. Istilah ini bermakna umum mencakup segala bentuk kekuasaan, dari mulai kekuasaan yang tinggi (khalifah), peradilan (al-qadha) dan advokasi (al-hisbah) hingga kekuasaan yang rendah meliputi seorang manusia saja. ${ }^{20}$ Menurut al-Thaybi, istilah tersebut zahirnya mu'annats namun bentuk ta'nits tersebut tidak

${ }^{19}$ al-Zahabiy, Siyar A 'lam al-Nubala', Juz II, h. 571, Muslim ibn al-Hajjaj, al-Kuniy wa al-Asma', Juz I, h. 353. al-Bukhari, al-Tarikh al-Kabir, Juz V, h, 242. Ibnu Hajar al-'Asqalani, Tahdzib al-Tahdzib, (Beirut: Dar al-Fikr, 1984), Juz VI, h. 173, al-Kalabadzi, Rijal Shahih al-Bukhari, Juz I, h. 439. Ibnu Abi Hatim, al-Jarh wa al-Tádil, Juz V, h. 238, Ibnu Hibban, alTsiqat, Juz III, h. 249. al-Zahabiy, Mizan al-I'tidal fi Naqd alRijal, Juz V, h. 497.

${ }^{20}$ al-Shan'ani, Subul al-Salam, Juz IV, h. 116. mencakup maknanya. (ghairu haqiqiyyin), melainkan menunjukkan ungkapan terhadap kekuasaan yang ada pada saat itu. Ahli bahasa yang lain menjelaskan bahwa istilah "al-imarah" itu bentuk muannats dalam lafadz, namun tidak dalam dalam makna. Hal itu menunjukkan cakupan makna yang luas. Istilah itu juga tidak digunakan untuk subjek ( $f$ 'ail) dalam bentuk jama', melainkan digunakan untuk subjek mufrad. ${ }^{21}$

Menurut al-Mundziri, mengenai hukum meminta jabatan para ulama berbeda pendapat apakah boleh atau dilarang? Ada yang berpendapat kalau untuk memperoleh kehidupan pribadi hukumnya makruh, dan jika untuk menegakkan kebenaran maka hukumnya jaiz. ${ }^{22}$

Pada hadis di atas Rasulullah saw melarang berambisi dalam meraih jabatan, baik dengan cara yang haram maupun dengan cara yang dibolehkan, kecuali kalau ditunjuk atau diminta oleh khalayak. ${ }^{23}$ Dari sini bisa juga ditarik pemahaman bahwa meminta jabatan yang berhubungan dengan pemerintahan maka hukumnya makruh, termasuk di sini meminta jabatan kepala pemerintahan (imarah), hakim (qadhi), polisi dan lain-lain. ${ }^{24}$ Ini karena keinginan yang sangat kuat dan ambisinya yang terlalu berlebihan, padahal ia mengetahui akan banyaknya hambatan-hambatan yang akan dihadapinya kelak dan sulitnya berlaku ikhlas dalam menjalankan tugasnya. Hal ini juga menjadi indikasi bahwa yang bersangkutan menginginkan jabatan itu lebih dominan untuk kepentingan dirinya sendiri dan untuk tujuantujuan tertentu. Yang demikian itu tentu akan menyulitkan dirinya berlaku adil karena nafsunya lebih menguasai atau telah mengalahkan dirinya sehingga dapat menjerumuskannya ke

\footnotetext{
${ }^{21}$ al-Shan'ani, Subul al-Salam, Juz IV, h. 117.

${ }_{22}$ Muhammad Syams al-Haq al-Azim Abadi Abu al-Thaib, 'Ain al-Ma'bud, (Beirut: Dar al-Kutub al-'Ilmiyah, 1415 H), Juz XXI, h. 244

${ }^{23}$ Ibn al-Hajar al-'Asqalaniy, Fath al-Bari Syarah Shahih alBukhari, (Beirut: Dar al-Fikr, t.th.), Juz IV, h. 441.

${ }^{24}$ al-Thaib, 'Ain al-Ma'bud, h. 245.
} 
dalam jurang kebinasaan/kehancuran. ${ }^{25}$ Kalimat "Wukilta" bermakna diserahkan sepenuhnya kepada orang yang meminta suatu jabatan. Karena orang yang meminta jabatan itu pasti menganggap dirinya telah mampu. Karena ia merasa telah mampu, maka Allah tidak akan memberikan petunjuk dan pertolongan-Nya dalam menjalankan tugasnya itu. Sebaliknya bagi orang yang tidak meminta, tetapi dipilih atau diberi mandat lalu ia dengan bertawakkal dan mengharap pertolongan Allah menerima jabatan itu, maka ia tidak dibebankan secara mutlak atas jabatannya itu, tetapi Allah ikut membantunya. ${ }^{26}$

Dalam syarah al-Nawawi disebutkan bahwa hadis tentang larangan meminta jabatan itu dipahami sebagai makruh hukumnya meminta jabatan dan orang yang memintanya tidak akan mendapat pertolongan (ma'unah) dari Allah $\mathrm{Swt}^{27}$ sehingga kepemimpinannya tidak akan berjalan dengan baik. ${ }^{28}$

Hadits di atas kiranya menjelaskan bahwa orang yang mencari dan meminta jabatan kepemimpinan secara tamak, dia akan ditinggalkan orang dan tidak mendapat dukungan mereka karena ketamakan atau kerakusannya itu. Dalam kepemimpinan atau masalah lain yang berhubungan dengan hukum, seperti masalah peradilan dan lain-lain, kerakusan dan ketamakan menjadi faktor penyebab yang dapat menghalagi untuk tercapainya sebuah keinginan. Hal ini karena orang yang memiliki sifat tamak dan rakus, dalam hal ini adalah terhadap jabatan kepemimpinan, dia akan melihat jabatan kepemimpinan sebagai lahan mata pencaharian untuk memperoleh kekayaan duniawi dan dia akan menghalalkan berbagai macam cara untuk memperoleh apa yang diinginkannya. Oleh sebab itu, masyarakat yang jeli tehadap hal ini

${ }^{25}$ Abd al-Rauf al-Manawi, Faidh al-Qadir Syarh Jami' alShaghir, (Mesir: Maktabah al-Tijariyah al-Kubra, 1356 H), Cet. I, Juz II, h. 550.

${ }^{26}$ al-Thaib, 'Ain al-Ma'bud, h. 246.

${ }^{27}$ Abu Zakariya Yahya ibn Syarif ibn Mary al-Nawawi, Syarh al-Nawawi 'ala Shahih al-Bukhari, (Beirut: Dar Ihya al-Turats al-'Arabi, 1392 H), Juz XI, h. 116.

${ }^{28}$ al-Nawawi, Syarh al-Nawawi, Juz XII, h. 209. tidak akan memberikan kepercayaan kepadanya untuk mengurusi permasalahan mereka.

Namun, ini tidak berarti bahwa semua orang harus bersikap pasif atau tidak proaktif terhadap fenomena pemerintahan yang terjadi di sekitarnya. Apabila seseorang dianggap mampu untuk merealisasikan keadilan dalam sebuah kepemimpinan, dia dapat diajukan atau mengajukan diri untuk menjabatnya. Dalam sejarah disebutkan bahwa Nabi Yusuf as pernah meminta jabatan kekuasaan karena ia mengetahui betul bahwa saat itu tidak ada seorangpun yang mampu menjabat jabatan tersebut sekaligus dapat berlaku adil dan bisa memperbaiki distribusi hak-haknya orang fakir miskin. Maka dalam keadaan seperti Yususf as itu, hukumnya wajib bagi orang yang punya kemampuan (capability, kompetensi) untuk memimpin dan meminta jabatan tersebut dengan memperkenalkan dan menjelaskan sifat-sifat yang dimilikinya, kemampuan ilmunya, dan cara yang akan ditempuhnya untuk menangani masalah-masalah. Namun jika ia tahu masih ada orang lain mampu juga melaksanakannya, maka lebih diutamakan sebaiknya ia tidak meminta jabatan tersebut. ${ }^{29}$ Apalagi jika ia melihat atau mengetahui ada orang lain yang lebih baik dan lebih mampu dari dirinya, maka kalaupun ia sudah mengucapkan sumpah (jabatan) dan sedang memangku jabatan tersebut, hendaklah ia membatalkan sumpahnya terhadap jabatan tadi tanpa membayar kafarat, dan menyerahkan jabatannya tersebut kepada orang yang lebih baik (ahli/kompeten) darinya. ${ }^{30}$ Kenyataan ini dilegitimasi oleh pernyataan hadits Rasulullah saw. yang dikeluarkan oleh Abu Dawud dari Abu Hurairah, sebagai berikut:

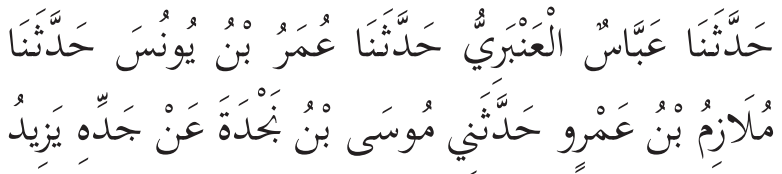

${ }^{29}$ Muhammad ibn Ahmad ibn Abi Bakar ibn Farh alQurtubi, al-Jami' Li Ahkam al-Qur'an, (Mesir: Dar al-Sya'bi, 1372H), Cet. II, Juz IX, h. 216.

${ }^{30}$ Ismail ibn Umar ibn Katsir al-Dimasyq, Tafsir al-Qur'an al-'Azhim, (Beirut: Dar al-Fikr, 1401H), Juz I, h. 267. 


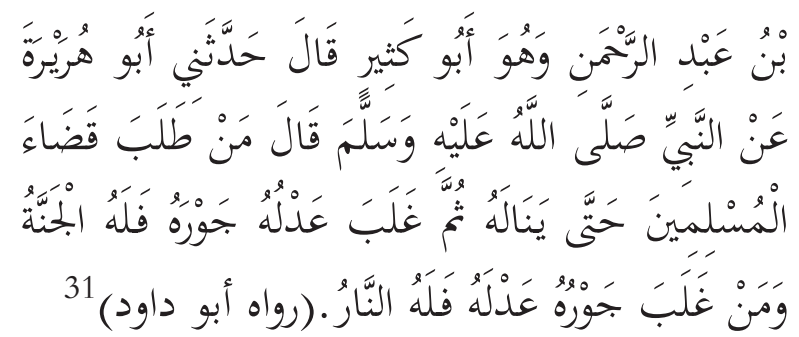

"Diceritakan kepada kami oleh Abbas al-Anbariy, diceritakan kepada kami oleh Umar ibn Yunus, diceritakan kepada kami oleh Mulazim ibn Amr dan diceritakan kepada kami oleh Musa ibn Najdah dari kakeknya Yazid ibn Abdirrahman, dan dia adalah Abu Katsir berkata, diceritakan kepadaku oleh Abu Hurairah dari Nabi saw bersabda: "Barang siapa yang meminta (jabatan) untuk mengurusi permasalahan orang-orang muslim kemudian dia memperolehnya, apabila keadilannya dapat mengalahkan ketidakjujurannya, maka baginya surga; dan apabila ketidakjujuran dapat mengalahkan keadilannya, maka baginya neraka." (HR. Abu Dawud)

\section{Tinjauan Sanad:}

Abbas al-Anbariy nama lengkapnya adalah Abbas ibn Abd al-Azhim al-Anbariy, kuniyahnya Abu Fadhl. Ia termasuk tingkatan Tabi atTabiin pertengahan yang menurut Abu Hatim, ia orang yang shaduq, bermukim di Bashrah dan wafat tahun $240 \mathrm{H}$. Ia adalah orang yang hafiz dan tsiqah. ${ }^{32}$

Umar ibn Yunus nama lengkapnya adalah Umar ibn Yunus ibn Qasim al-Hanafiy al-Jarsyi, kuniyahnya Abu Hafsh. Ia termasuk tingkatan Tabïin kecil, bermukim di Yamamah dan wafat tahun 206 H. Menurut Ahmad, Ibnu Ma in dan Nasa'i, ia adalah orang yang tsiqah. ${ }^{33}$

${ }^{31}$ Sulaiman ibn Asyats Abu Dawud al-Sijistani al-Azdiy, ditahqiq oleh Muhammad Muhyiddin Abd al-Hamid, Sunan Abi Dawud, (Beirut: Dar al-Fikr, t.th.), Juz III, h. 299 dalam Kitab al-Aqzhiyah, Bab Fi al-Qadhi Yukhtha’u, No. Hadits 3104.

${ }^{32}$ Muslim, al-Kuniy wa al-Asma', Juz I, h. 676. al-Bukhari, alTarikh al-Kabir, Juz VII, h. 6. al-'Asqalaniy, Taqrib al-Tahdzib, Juz I, h. 293. Hamd ibn Ahmad Abu Abdillah al-Zahabiy, alKasyif (Jeddah: Dar al-Qiblah li al-Tsaqafah al-Islamiyah, 1992), Cet. I, Juz I, h. 535. al-Kalabadzi, Rijal Shahih al-Bukhari, Juz II, h. 879. Ibnu Abi Hatim, al-Jarh wa al-Ta'dil, Juz VI, h. 216. Ibnu Hibban, al-Tsiqat, Juz VIII, h. 511.

${ }^{33}$ Muslim, al-Kuniy wa al-Asma', Juz I, h. 205. al-Bukhari,
Mulazim ibn Amrin nama lengkapnya adalah Mulazim ibn Amru ibn Abdullah al-Hanafi alSahimiy, kuniyahnya Abu Amru, laqabnya Lazim. Ia termasuk tingkatan Tabiin tengah, bermukim di Yamamah dan tidak diketahui kapan dan dimana wafatnya. Ia adalah orang yang shaduq. ${ }^{34}$

Musa ibn Najdah nama lengkapnya Musa ibn Najdah al-Hanafiy. Ia tidak berjumpa dengan Rasul, majhul, dan bermukim di Yamamah. ${ }^{35}$

Yazid ibn Abdurrahman nama lengkapnya adalah Yazid ibn Abdurrahman al-Sahyi alGhabari, kuniyahnya Abu Katsir. Lahir tahun 60 $\mathrm{H}$ dan wafat tahun $130 \mathrm{H}$. Ia termasuk tingkatan Tabiin pertengahan, sangat menguasai masalah peradilan dan bermukim di Yamamah. Ia adalah orang yang tsiqah. ${ }^{36}$

\section{Tinjauan Matan:}

Hadis di atas kualitasnya shahih, marfu' muttashil, dan hanya dijumpai dalam Sunan Abi Dawud (infarada bihi Abu Dawud)

Dari keterangan hadis di atas dapat diketahui bahwa perolehan surga, baik surga duniawi yang berupa dukungan sosial dalam kepemimpinannya maupun surga ukhrawi yang berupa pertolongan Allah dan balasan terhadap keadilannya dalam kepemimpinannya atau neraka bukanlah ditentukan oleh pengajuan dirinya untuk diangkat sebagai pemimpin (hakim), melainkan ditentukan oleh

al-Tarikh al-Kabir, Juz II, h. 206. Ibnu Abi Hatim, al-Jarh wa alTa'dil, Juz VI, h. 142. Ibnu Hibban, al-Tsiqat, Juz VIII, h. 445. al-`Asqalaniy, Tahdzib al-Tahdzib, Juz VII, h. 445

${ }^{34}$ Muslim, al-Kuniy wa al-Asma', Juz I, h. 571. al-Bukhari, al-Tarikh al-Kabir, Juz VIII, h. 73. Ibnu Abi Hatim, al-Jarh wa al-Ta'dil, Juz VIII, h. 435. al-'Ijliy, Ma;rifat al-Tsiqat, Juz II, h. 296. Ibnu Hibban, As-Tsiqat, Juz IX, h. 195. al-Zahabiy, Mizan al-I'tidal, Juz VI, h. 512. al- 'Asqalani, Taqrib al-Tahdzib, Juz I, h. 555. Hamd ibn Ahmad, al-Kasyif, Juz II, h. 310. Yusuf ibn alZakiy Abdurrahman Abu al-Hajjaj al-Miziy, Tahdzib al-Kamal, Juz XXIX, h. 188

35 al-'Asqalani, Tahdzib al-Tahdzib, Juz VI, h. 334. al'Asqalaniy, Taqrib al-Tahdzib, Juz I, h. 554. Hamd ibn Ahmad, al-Kasyif, Juz II, h. 309. al-Miziy, Tahdzib al-Kamal, Juz XXIX, h. 161. al-Zahabi, Mizan al-I tidal, Juz VI, h. 566.

${ }^{36}$ Ahmad ibn hambal Abu 'Abdillah al-Syaibani, al-Asaama wa al-Kuniy Li Ibni Hambal, (Kuwait: Maktabah Dar al-Aqsha, 1985), Cet. I, Juz I, h. 50 Ibnu Hibban, Masyahir, Juz I, h. 118, 123. al Asqalani, Tahdzib at-Tahdzib, Juz XI, h. 301. Hamd ibn Ahmad, al-Kasyif, Juz II, h. 453. al-`Ijliy, Ma;rifat al-Tsiqat, Juz II, h. 365. Ibnu Hibban, al-Tsiqat, Juz V, h. 539. 
kesanggupan dirinya untuk bersikap adil dan tidaknya dalam menjalankan roda kepemimpinan terhadap orang-orang yang berperkara. Terlebih lagi jika saat itu diduga kuat tidak ditemukan orang lain selain dirinya yang diperkirakan dapat berlaku adil seperti dirinya, maka yang bersangkutan selayaknya mengajukan dirinya terhadap jabatan tersebut. ${ }^{37}$ Namun apabila seseorang dianggap tidak mampu merealisasikan sikap yang akan membawa dirinya untuk memperoleh dukungan sosial dan pertolongan Allah, yakni keadilan, maka orang tersebut tidak layak untuk dijadikan sebagai hakim. Yang demikian itu menurut al-Shan'ani bisa terjadi diakibatkan oleh diserahkannya jabatan hakim kepada orang yang bodoh (jahil). ${ }^{38}$

Dukungan sosial dan pertolongan Allah sangat diperlukan dalam mengurusi masalah umat. Hal ini karena dalam mengurusi umat terdapat berbagai kesulitan yang tidak mungkin dapat ditangani sendiri oleh seorang pemimpin. Tanpa dukungan dan pertolongan tersebut, seorang pemimpin umat akan menjadi penyebab kehancuran dirinya dan juga masyarakatnya. Berkenaan dengan pertolongan ini, di dalam hadis marfu' yang diriwayatkan oleh Bilal bin Mardas dari Khaitsaman, dijelaskan sebagai berikut:

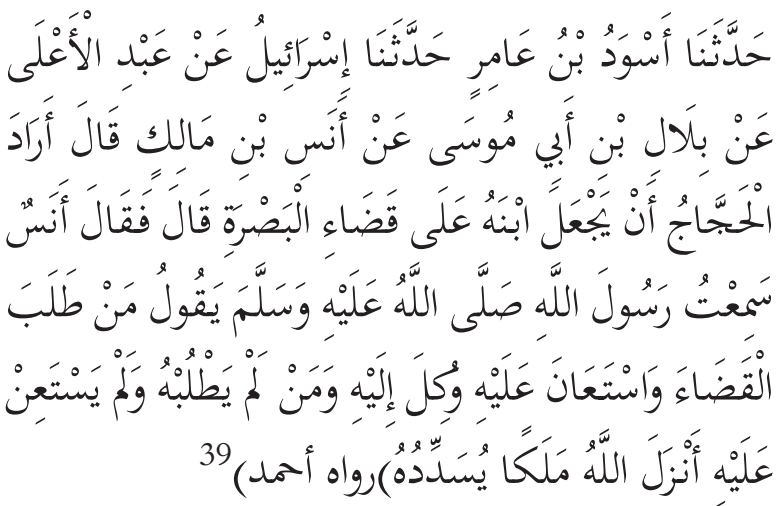

"Diceritakan kepada kami oleh Aswad ibn "Amir, diceritakan kepada kami oleh Israil dari Abd alA'la dari Bilal dari Abi Musa dari Anas ibn Malik berkata, al-Hajjaj berkeinginan menjadikan anaknya sebagai hakim di Bashrah. Maka Anas

${ }^{37}$ Muhammad ibn Ali ibn Muhammad al-Syaukani, Nail al-Authar, (Beirut: Dar al-Jalil, 1973), Juz IX, h. 158

${ }^{38}$ al-Shan'ani, Subul al-Salam, Juz IV, h. 116.

${ }^{39}$ Ahmad Ibn Hanbal Abu Abdillah al-Syaibani, Musnad Ahmad, (Mesir: Muassasah Qurtubah, t.th.), Juz III, h. 220, No. Hadits. 12824 berkata, saya telah mendengar Rasulullah saw bersabda: "Barang siapa yang meminta jabatan kepemimpinan dan meminta dukungan kepada para pembantunya (secara tamak), dia akan dibebani untuk memikulnya sendiri. Dan barang siapa yang tidak memintanya, maka Allah akan menurunkan malaikat yang akan meluruskannya (menolongnya)". (HR. Ahmad)

\section{Tinjauan Sanad:}

Aswad ibn 'Amir nama lengkapnya alAswad ibn 'Amir, ia merupakan Tabi al-Tabiin kecil, nasabnya adalah al-Syamiy, kuniyahnya Abu Abdirrahman, laqabnya adalah Syazan. Ia aslinya berasal dari Syam lalu menetap di Baghdad dan meninggal di sana pada tahun 208 H. Ia tergolong rawi yang shaduq, shalih, dan tsiqah. ${ }^{40}$

Israil nama lengkapnya adalah Israil ibn Yunus ibn Ishaq, ia tergolong dalam tabaqah Tabi' at-Tabiin besar, nasabnya adalah al-Sabi'iy al-Hamdany, kuniyahnya adalah Abu Yusuf, ia merupakan penduduk Kufah, meninggal tahun $160 \mathrm{H}$. Ia merupakan perawi yang tsiqah. ${ }^{41}$

Abdul 'Ala bernama lengkap Abdul 'Ala ibn 'Amir, ia tidak berjumpa dengan sahabat, nasabnya al-Tsa'labiy, ia bermukim di Kufah. Ia wafat tahun $129 \mathrm{H}$ namun tidak diketahui di mana tempatnya. Ia tergolong Rawi yang shuduq tapi waham. ${ }^{42}$

${ }^{40}$ Muslim, al-Kuniy wa al-Asma', Juz I, h. 527. Al-Bukhari, al-Tarikh al-Kabir, Juz I, h. 448. al-'Asqalani, Tahdzib atTahdzib, Juz I, h. 297. Hamd ibn Ahmad, al-Kasyif, Juz I, h. 251. al-Miziy, Tahdzib al-Kamal, Juz III, h. 226. Ibnu Abi Hatim, Al-Jarh wa at-Ta'dil, Juz II, h. 294. Ibnu Hibban, alTsiqat, Juz VIII, h. 130

${ }^{41}$ al-Zahabiy, Siyar A Yam an-Nubala', Juz VII, h. 355. alBukhari, al-Tarikh al-Kabir, Juz II, h. 56. al'Asqalani, Masyahir, Juz I, h. 169. al-`Asqalani, Tahdzib al-Tahdzib, Juz I, h. 229. al'Asqalaniy, Taqrib al-Tahdzib, Juz I, h. 104. al-Miziy, Tahdzib alKamal, Juz II, h. 515. al-Kalabadzi, Rijal Shahih al-Bukhari, Juz I, h. 95. al-Zahabiy, Mizan al-I'tidal, Juz I, h. 365. Ibnu Abi Hatim, al-Jarh wa al-Ta'dil, Juz II, h. 330. al-'Ijliy, Ma'rifat al-Tsiqat, Juz I, h. 222. Ibnu Hibban, al-Tsiqat, Juz VI, h. 79.

${ }^{42}$ al-Bukhari, al-Tarikh al-Kabir, Juz VI, h. 71. al-'Asqalani, Tahdzib at-Tahdzib, Juz VI, h. 86. al-'Asqalaniy, Taqrib atTahdzib, Juz I, h. 331. Hamd ibn Ahmad, al-Kasyif, Juz I, h. 611. Ibnu Abi Hatim, al-Jarh wa at-Ta'dil, Juz VI, h. 25. Abdurrahman ibn Ali ibn Muhammad al-Jauziy, al-Dhu 'afa' wa al-Matrukin li Ibni al-Jauzi, (Beirut: Dar al-Kutub al-'Ilmiyyah, 1406 H), Cet. I, 
Bilal ibn Abi Musa mempunyai nama lengkap Bilal ibn Abi Burdah ibn Abu Musa, ia tergolong ke dalam tabaqat Tabiin kecil, nasabnya al-Asy'ariy, kuniyahnya adalah Abu 'Amru. Ia bermukim di Bashrah, pernah menjadi pemimpin (Amir) dan hakim (Qadhi) di sana. Tidak ditemukan tempat dan tahun wafatnya. Ia termasuk dalam tingkatan perawi yang maqbul (dapat diterima) riwayatnya. ${ }^{43}$

Anas ibn Malik bernama lengkap Anas ibn Malik ibn Nadhar ibn Dhamdham ibn Zaid ibn Haram, termasuk kepada tabaqat sahabat, nasabnya al-Anshariy al-Madany, kuniyahnya Abu Hamzah. Ia merupakan sahabat sekaligus pembantu Rasulullah Saw. Ketika Rasul datang ke Madinah, ia berumur 10 tahun, dan saat Rasul wafat, ia berumur 20 tahun, kemudian ia pindah ke Bashrah dan wafat di sana pada tahun $91 \mathrm{H}$. Karena ia merupakan seorang sahabat, maka ia berada dalam kategori golongan yang tertinggi tingkatan kualitas rawi. ${ }^{44}$

\section{Tinjauan Matan:}

Hadis di atas kualitasnya shahih, marfu:. Hadis ini juga dijumpai dalam Sunan al-Tirmidzi pada kitab al-Ahkam 'an Rasulillah nomor hadis 1245, Sunan Abi Dawud pada kitab al-Aqdiyah nomor hadis 2107, dan Sunan Ibnu Majah pada kitab al-Abkam nomor hadis 2300.

Matan hadis tersebut menjelaskan bahwa usaha meraih pekerjaan atau jabatan tertentu seperti hakim, tidak boleh didasari atas nepotisme. Selain itu, hadis tersebut juga mencela orang yang meminta jabatan kepemimpinan dengan cara meminta bantuan pada orang-orang yang men-

Juz II, h. 81. al-Zahabiy, Mizan al-I`idal, Juz IV, h. 235. Ahmad ibn Syu'aib al-Nasa'i, al-Dhu'afa' wa al-Matrukin li al-Nasa'i, (Halb: Dar al-Wa'yi, 1369 H), Cet. I, Juz I, h. 69.

${ }^{43}$ al-Bukhari, al-Tarikh al-Kabir, Juz II, h. 109. al-'Asqalaniy, Taqrib at-Tahdzib, Juz I, h. 129. Hamd ibn Ahmad, al-Kasyif, Juz I, h. 276. Ibnu Hibban, al-Tsiqat, Juz VI, h. 91.

${ }^{44}$ Muslim, al-Kuniy wa al-Asma', Juz I, h. 243. al-Bukhari, al-Tarikh al-Kabir, Juz II, h. 27. Ibnu Abi Hatim, al-Jarh wa al-Ta'dil, Juz II, h. 286. al'Asqalani, Tahdzib al-Tahdzib, Juz I, h. 329. al-'Asqalaniy, Taqrib al-Tahdzib, Juz I, h. 115. al-Miziy, Tahdzib al-Kamal, Juz III, h. 353. al-'Al-'Asqalani, Ishabah, Juz I, h. 126. al-`Ijliy, Ma rifat al-Tsiqat, Juz I, h. 236. Ibnu Hibban, al-Tsiqat, Juz III, h. 4. dukungnya atau yang dikenalnya. Karena hal itu berarti ia minta dipilih yang menandakan ia sangat berkeinginan (thama') terhadap jabatan tersebut dengan tujuan-tujuan tertentu yang bersifat duniawi. Oleh sebab itu, jika ia mendapatkan jabatan tersebut, maka yang bersangkutan tidak akan mendapatkan pertolongan dari Allah dalam melaksanakan tugas-tugasnya sehingga akhirnya jabatan yang disandangnya menjadi beban bagi dirinya, karena selalu menemukan kesulitan yang memberatkan dirinya dalam menjalankan kepemimpinannya.

Sebaliknya, jika seseorang menerima jabatan kepemimpinan tanpa meminta-minta jabatan tersebut, maka Allah senantiasa menolongnya melalui perantaraan malaikat-Nya yang selalu menunjukkannya ke arah kebaikan dan kemashlahatan, sehingga iapun dapat menjalankan tugas-tugas kepemimpinan dengan mudah, lancar dan sukses dalam mengemban amanah jabatannya.

\section{Penutup}

Dengan demikian, dapatlah kiranya ditarik benang merah bahwa hadis-hadis yang membicarakan tentang larangan ambisi meraih jabatan kepemimpinan adalah bermaksud sebagai berikut:

Pertama, Larangan memberikan jabatan pemerintahan, kehakiman atau jabatan penting lainnya yang termasuk jabatan publik kepada orang yang meminta, itu ditujukan kepada orang yang tamak dan tidak kompeten. Karena orang seperti itu akan menyalahgunakan jabatannya untuk kepentingan pribadi atau kelompok, dan ia pun tidak bisa menjalankan tugas sesuai jabatannya yang dapat merugikan masyarakat.

Kedua, Tidak ada larangan bagi orang yang sanggup berlaku adil untuk mengajukan dirinya sebagai pemimpin yang akan mengurus permasalahan umat. Apalagi kalau yang bersangkutan mempunyai kemampuan yang lebih di banding kandidat lainnya, baik kemampuan intelektual, manajerial atau kelebihan lain yang dapat mendukung kepemimpinannya kelak. 
Hadis tersebut tampaknya bukanlah termasuk hadis hukum, tapi lebih dekat kepada hadis tentang etika (akhlak). Jadi larangannya tidak berarti haram, tapi sekedar makruh.

Ketiga, Berbagai permasalahan harus diserahkan kepada orang yang layak dan ahli dalam bidangnya untuk mengurus dan menyelesaikannya. Khusus untuk jabatan pemimpin, hendaknya jabatan tersebut diserahkan kepada orang yang terbaik dari anggota masyarakatnya. Sehingga ia benar-benar akan dihargai, dipatuhi, dan mendapat dukungan sosial yang luas.

\section{Pustaka Acuan}

'Asqalani, Ahmad ibn Ali ibn Hajar al-. al-Ishabah, Beirut: Dar al-Jalil, 1992, Cet. I, Juz IV.

'Asqalani, Ahmad ibn Ali ibn Hajar al-. Fath alBari Syarah Shahih al-Bukhari, Beirut: Dar al-Fikr, t.th., Juz IV.

'Asqalani, Ahmad ibn Ali ibn Hajar al-. Taqrib al-Tahdzib, Suriya: Dar al-Rasyid, 1986, Cet. I, Juz I.

Azdiy, Sulaiman ibn Asyats Abu Dawud alSijistani al-. ditahqiq oleh Muhammad Muhyiddin Abd al-Hamid, Sunan Abi Dawud, Beirut: Dar al-Fikr, t.th., Juz III.

Bajiy, Abu al-Walid al-. al-Tajrih wa al-Ta'dil, Riyadh, Dar al-Liwa', 1986, Juz III.

Bukhari, Muhammad ibn Ismail Abu Abdillah al-, al-Tarikh al-Kabir, Juz IV.

Bukhari, Muhammad ibn Ismail Abu Abdillah al-. Shahih al-Bukhari, Beirut: Dar Ibnu Katsir, 1907, Cet. III, Juz VI

Daruqutniy, Abi al-Hasan ibn Ali ibn Umar ibn Ahmad al-. Zikru Asma' al-Tabi in wa Man Ba'dahum, Beirut: Mu'assasah al-Kutub alTsaqafiyah, 1985, Cet. I, Juz I.

Dimasyq, Ismail ibn Umar ibn Katsir al-. Tafsir al-Qur'an al-'Azhim, Beirut: Dar al-Fikr, 1401H., Juz I.

Hajjaj, Muslim ibn al-. al-Kuniy wa al-Asma', Suriya: Dar al-Rasyid, 1986, Juz I.
Hibban, Ibnu. Masyahir Ulama' al-Amshar, Beirut: Dar al-Kutub al-'Ilmiyyah, t. th., Juz I.

Husaini, Ibrahim ibn Muhammad al-. ditahqiq oleh Saifuddin al-Katib, al-Bayan wa al-Tärif, Beirut: Dar al-Kitab al-Arabiy, 1401H, Juz I

Kalabadzi, Abu Nashr al-. Rijal Shahih alBukhari, Beirut: Dar al-Ma`rifah, 1987.

Manawi, Abd al-Rauf al-. Faidh al-Qadir Syarh Jami' al-Shaghir, Mesir: Maktabah alTijariyah al-Kubra, 1356 H, Cet. I, Juz II.

Miziy, Yusuf ibn al-Zakiy Abdurrahman Abu alHajjaj al-. Tahdzib al-Kamal, Juz XXIX

Nawawi, Abu Zakariya Yahya ibn Syarif ibn Mary al-. Syarh al-Nawawi ala Shahih al-Bukhari, Beirut: Dar Ihya al-Turats al'Arabi, 1392 H,, Juz XI.

Qurtubi, Muhammad ibn Ahmad ibn Abi Bakar ibn Farh al-. al-Jami Li Ahkam al-Qur'an, Mesir: Dar al-Sya'bi, 1372H., Cet. II, Juz IX.

Shan'ani, Muhammad ib Ismail al-. Subul alSalam Syarh Bulugh al-Maram Min Adillat al-Ahkam, (Beirut: Dar Ihya al-Turas alArabiy, 1379H), Juz II

Suyuthi, Abdurrahman ibn Abi Bakr al-. Thabaqat al-Huffaz, (Beirut: Dar Al-Kutub al-'Ilmiyyah, 1403H), Juz I.

Syaibani, Ahmad ibn hambal Abu `Abdillah al-. alAsaama wa al-Kuniy Li Ibni Hambal, Kuwait: Maktabah Dar al-Aqsha, 1985, Cet. I, Juz I.

Syaukani, Muhammad ibn Ali ibn Muhammad. Nail al-Authar, Beirut: Dar al-Jalil, 1973, Juz IX.

Thaib, Muhammad Syams al-Haq al-Azim Abadi Abu al-. 'Ain al-Ma'bud, Beirut: Dar al-Kutub al-'Ilmiyah, 1415 H., Juz XXI.

Wa izh, Umar ibn Ahmad Abu Hafsh al-. Tarikh Asma’ al-Tsiqat, Kuwait: al-Dar al-Salafiyah, Cet. I, Juz I.

Zahabiy, Hamd ibn Ahmad Abu Abdillah al-. alKasyif, Jeddah: Dar al-Qiblah li al-Tsaqafah al-Islamiyah, 1992, Cet. I, Juz I. 